lecturer of the University of Notre Dame in 1961, and delivered the Remson Memorial Lecture of the American Chemical Socicty in 1962. Prof. P'orter has a deep interest in scientific education as well as in scientific research, and is woll known for his lectures on chemistry to school children. 'The professorship in chemistry at the Royal Institution was revived for him in 1963, and he has given many loctures in this capacity, both to scientists and non-scientists, while also leading the Department of Chemistry in sheffield. It is to be hoped that this new appointment will give him the maximum opportunity for the advancernent of scientific research and education.

\section{National Institute of Agricultural Botany : \\ Establishment of Systematic Botany Branch}

A New Branch has been established within tho National Institute of Agricultural Botany. This will be known as tho 'Systematic Botany Branch' and will consolidate work on the description and identification of plant varieties, which is at present undertaken by Trials and Seed Production Branches. Anothor function of the new Branch will be to undertake tests on new plant varietios which are required under the Plant Varieties and Seeds Act, 1964. The Branch will form part of the Variety Classification Unit of the Plant Variety Rights Office and will provide information on varieties which have been submitted either for a grant of rights or for inclusion on the Index of Varieties. 'The Branch will also supply the rest of the Institute with information about the identification of varioties. This information will be particularly valuable in the planning of future trials to tost the merits of varieties, and later for the purpose of the various seed certification and seed crop approval schemes.

Mr. A. F. Kelly

The first head of the new Branch will be Mr. A. F. Kelly, who is transferring from his prosont post of head of Seed Production Branch. Mr. Kelly has been at the Institute since Juno 1945, when he assisted with the establishment and recording of the renowed programme of varicty trials after the Second World War. Later he was in charge of tho Institutie's seed multiplication work and the production of basic seed of varieties from the official Plant Breeding Stations from 1947 until 1954. In 1954 he was secondod to the Organization for European Economic Co-operation for two yoars to assist in the development of variety trials of grasses and clovers, and of an international agreement on seed cortification methods.

Mr. G. Finch

Mr. G. Finch, who has been appointed acting head of Seed Production Branch, is probably better known to vegetable growers than to farmers in general. He joined the National Institute of Agricultural Botany in 1946 and has boen specially concerned with the development of trials on varieties of vegetables throughout England and Wales. In his earlier years at the Institute he was responsible for the seed production side of the work as well as the variety trials and is consequently well known to most producers of root and vegetable seeds.

\section{The Shirley Institute}

Afrer forty years at Shirley Institute, Mr. L. H. C. Tippett and Mr. W. A. Richardson retired at the end of Jure. Both joined the staff on the same day and have seen the Institute grow from small beginnings to an organization with world-wide reputation.

\section{Mr. L. H. C. Tippett}

Mr. L. H. C. Tippett, assistant director in charge of physics and mechanical processing since 1951, has become internationally known for his work on operational research and statisties. Ho was a pioneer in the statistical invosti- gation of process operations in the textile industry. $\mathrm{He}$ has served on numerous committees concerned with statistics and allied topics. He was the first chairman of the Committee of Statistics in Industry and Technology of the International Statistical Institute and also the first chairman of the Textile Institute's Quality Control Group. He is now president of tho Royal Statistical Society. During the course of his career he has roceived a number of awards for his work, including the Guy Medal in Silver of the Royal Statistical Society and the Textile Institute's Warner Medal, In 1962 the American Society of Quality Control presented him with its Shewhart Medal for "his outstanding leadership in the field of modern quality control".

Mr. W. A. Richardson

The other member of staff retiring is Mr. W. A. Richardson, whose work as a senior finishing liaison officer since 1958 has brought him into contact with many peoplo in the industry. During the first twenty years of his Instituto carcer his research work on starch resulted in a notable contribution to the technology of warp sizing. From 1943 until 1958 he was head of the Rayon Department and becamo concerned in the ever-widening field of man-made fibre processing. He has sorved on several international and Textilo Institute committees concerned with the standardization of chemical methods to analysis of fibre mixtures.

\section{Royal Society Research Appointments}

THE Royal Society has announced the following appointments to fellowships, dated from October 1, for two years in the first instanco: $A \mathrm{Mr}$. and Mrs. John Jaffé Donation research fellowship, to Dr. R. F. Griffin to enable him to continue his work on (i) dircet photoelectric measurement of stellar radial velocities, (ii) photometric surveys of stcllar spectra at high resolution at the Obscrvatories, University of Cambridge; The Mackinnon research studentship, to Dr. $\boldsymbol{l}$. E. Baker to enable him to carry out studies on volcanological and petrological investigations on island-arcs and mid-ocean ridges at tho Department of Geology and Mineralogy, University of Oxford; A Stothert research fellowship, to Dr. C. L. Nobbs to enablo him to continue his work on the determination of the mode of attachment of oxygen to myoglobin of the sperm whale at the Modical Research Council Laboratory of Molecular Biology, Cambridge.

The first Bruno Mondel travelling fellowship has been awarded to Dr. R. Whittam, of the Depurtment of Biochemistry, University of Oxford, to enable him to work in the Department of Biophysies of the Weizmann Institute, Rehovoth, during the academic year 1965-66. This appointment has boon established with a gift from Mrs. Hertha Mendel to enable a travelling fellowship to bo awarded in successive years to British, Dutch and Israeli candidates to enable thom to work abroad in the United Kingdom, The Netherlands or Israel.

\section{Medical Research Council}

'THe Sccretary of State for Education aisd Scienco, Mr. A. Crosland, in consultation with the Medical Research Council and the Prosident of the Royal Society, has appointed the following to the Medical Research Council from October 1: Prof. D. G. Evans, Department of Bacteriology and Immunology, London School of Hygiene and Tropical Medicine; Prof. W. Melvillo Arnott, Department of Medicine, University of Birmingham; Prof. J. L. Gowans, Henry Dale professor of the Royes Society, Department of Pathology, University of Oxford. These members have been appointed in succession to Prof. M. M. Swann, who resigned from the membership of the Council on his appointment to the Council for Scientific Policy, and to Prof. Wilson Smith and Prof. M. L. Rosenheim, who are retiring on completion of their term of office. 